\title{
Obesity Levels in the Russian Federation- A Risk Reduction Portfolio Management Corporate Governance Approach to the Bio-Psycho-Social Influence of Marketing Projects in the Russian Fast Food Industry
}

\section{Valeriya Marchenko}

Strategic Entrepreneurship and Innovation Department, Russian Presidential Academy of National Economy and Public Administration (RANEPA), Russian Federation, Moscow, Russia

Email: Valeriya.marchenko@icloud.com

How to cite this paper: Marchenko, V. (2020). Obesity Levels in the Russian Federation-A Risk Reduction Portfolio Management Corporate Governance Approach to the Bio-Psycho-Social Influence of Marketing Projects in the Russian Fast Food Industry. Open Journal of Social Sciences, 8, 292-312.

https://doi.org/10.4236/jss.2020.88025

Received: July 22, 2020

Accepted: August 21, 2020

Published: August 24, 2020

Copyright $\odot 2020$ by author(s) and Scientific Research Publishing Inc. This work is licensed under the Creative Commons Attribution International License (CC BY 4.0).

http://creativecommons.org/licenses/by/4.0/

\begin{abstract}
The research is focused on determining Ethical Considerations of Obesity Levels in the Russian Federation-A Risk Reduction Portfolio Management Corporate Governance Approach to the Biopsychosocial Influence of Marketing Projects in the Russian Fast Food Industry. The birth of this idea is with Bombeck, who has authored more than 4000 newspaper columns about the day to day suburban life. The objectives of this research include: To know whether there is a link between fast food marketing in childhood and fast food consumption in adult life; whether a decline in children-oriented fast-food marketing campaigns causes lower obesity levels and associated economic and social problems and the last objective is to determine if a Russian Government Portfolio Management Framework would reduce the risks to the Russian economy with regards to the approach. A qualitative research method was used, which included literature review, survey and interviews. The findings of the research were; there is a link between fast food marketing campaigns in childhood and consumer behavior in adulthood. A decline in campaigns leads to a reduction in obesity levels and associated costs. The Russian government portfolio Management Framework will reduce obesity risks in the country. In conclusion, various steps need to be made to reduce the increase in obesity and the diseases that accompany it. Society, together with the government, should seek stringent measures to prevent manufacturers from exploiting the ill-informed masses. The curriculum in schools should be modeled to incorporate health and fitness. Besides, people need to change their mindset con-
\end{abstract}


cerning fast foods. However, this cannot be achieved unless the government is willing to place employ stringent measures.

\section{Keywords}

Obesity, Russian Federation, Marketing

\section{Introduction}

The author's interest is to find solutions that would help Russian Federation Administration to stop obesity spreading among adults, children and elderly people. Obesity can cause chronic diseases such as cardiovascular diseases, musculoskeletal disorders and some cancers (World Health Organization, 2019). The author's desire is to make the nation healthy and then the world.

\subsection{Background}

According to the World Health Organization report the rate of obesity is continuously increasing health problems among children (World Health Organization, 2019). Specifically, for the Russian Federation the number of obese has increased in five years (2011-2016) by $50 \%$ (Alter, 2018). A complex coordinated and planned response is required as obesity levels rise. First, we need to understand the nature of obesity as a medical and physical condition before we can look at adaptive responses.

Obesity is a condition of excess body fat due to which the number and size of fat cells increase. Obesity affects health status and can cause chronic diseases such as cardiovascular diseases, musculoskeletal disorders and some cancers (World Health Organization, 2019). The presence of obesity is commonly assessed by calculating the BMI which is a simple index of weight-for-height that is used to classify overweight and obesity in adults. It is defined as a person's weight in kilograms divided by the square of his height in meters $\left(\mathrm{kg} / \mathrm{m}^{2}\right)(\mathrm{Cdc} . g \circ$, 2019).

According to comprehensive research findings at the institute of health metrics, there is a global increase of obesity and overweight at a rate of $27.5 \%$, with about $47.1 \%$ increment in children and adolescence over the preceding 33 years (Whiteman, 2014). Studies carried out between 2012 and 2014 show that approximately $30 \%$ of Russian adults had obesity, which is closely approaching figures in the USA, currently at 34.9\% (Kontsevaya et al., 2019: p. 104). Other research carried out between 2011 and 2014 found about $64.6 \%$ of Russian adults to have a BMI of more than $25 \mathrm{~kg} / \mathrm{m}^{2}$, again showing signs of approaching USA prevalence level of $68 \%$ (Malik, Willett, \& Hu, 2013). According to a 25-year study conducted to investigate obesity trends in Russia, the lifestyle problem had attained a 45.5\% increase between 2011 and 2016 (Alter, 2018).

This thesis takes a view that obesity begins in childhood and manifests itself in 
physical and mental distress in adulthood-it will propose that the Government Committee should take a Portfolio approach with future efforts; such as high school education (sports and cooking), health promotion (work incentives through businesses and medical practitioners), sector specific targeting (supermarkets by law cannot sell Sugar Soda to children).

\subsection{Research Objectives}

There are three objectives, these are: to provide data on past, current and projected levels of obesity since 1950-2050 in comparing the USA and USSR/Russian Federation over same time period; to use case study analysis of fast food outlet McDonald's to analyze their marketing strategy towards children; to determine if a Russian Government Portfolio Management Framework would reduce the risks to the Russian economy in Table 1. The link between Objectives/Questions/Propositions outlines the scope of the research.

\section{Literature Review}

The literature review was sourced from articles, scientific journals, books and

Table 1. Objectives, questions and proposition tree.

\begin{tabular}{|c|c|c|}
\hline Objectives & Questions & Propositions \\
\hline $\begin{array}{l}\text { 1) To provide data on past, } \\
\text { current and projected levels } \\
\text { of obesity since } 1950-2050 \\
\text { in comparing the USA and } \\
\text { USSR/Russian Federation } \\
\text { over same time period. }\end{array}$ & $\begin{array}{l}\text { a) Is there a link } \\
\text { between fast food } \\
\text { marketing in } \\
\text { childhood and fast } \\
\text { food consumption in } \\
\text { adult life? }\end{array}$ & $\begin{array}{l}\text { iii) Marketing forms stereotypical attitudes and } \\
\text { gives bias }\end{array}$ \\
\hline $\begin{array}{l}\text { 2) To use case study analysis } \\
\text { of fast food outlet } \\
\text { McDonald's to analyze their } \\
\text { marketing strategy towards } \\
\text { children. }\end{array}$ & $\begin{array}{l}\text { a) Will a decline in } \\
\text { children oriented fast } \\
\text { food marketing } \\
\text { campaigns cause } \\
\text { lower obesity levels } \\
\text { and associated } \\
\text { economic and social } \\
\text { problems? }\end{array}$ & $\begin{array}{l}\text { i) Gifts to children make them want fast food } \\
\text { more } \\
\text { ii) Less consumption of fast food will lead to a } \\
\text { healthier life } \\
\text { iii) Less consumption of fast food will stimulate } \\
\text { children's brain work } \\
\text { iv) Decline in Obesity rates will result in } \\
\text { Growing Economy }\end{array}$ \\
\hline $\begin{array}{l}\text { 3) To determine if a Russian } \\
\text { Government Portfolio } \\
\text { Management Framework } \\
\text { would reduce the risks to } \\
\text { the Russian economy. }\end{array}$ & $\begin{array}{l}\text { a) Will a risk-based } \\
\text { approach to Portfolio } \\
\text { Management } \\
\text { Framework at } \\
\text { Government Level } \\
\text { lead to decreased } \\
\text { obesity rates among } \\
\text { children? }\end{array}$ & $\begin{array}{l}\text { i) Government change to labeling food rules } \\
\text { will reduce extra calories consumed (how much } \\
\text { calories in a package, not in } 100 \mathrm{~g} \text { ) } \\
\text { ii) Government restriction to sell fast food in } \\
\text { schools will reduce obesity rates in the future } \\
\text { iii) Government restriction to direct } \\
\text { commercials towards children will } \\
\text { reduce obesity rates }\end{array}$ \\
\hline
\end{tabular}


research papers. It was gathered from 1950's till now. Since 1950 data shows an increased calorie consumption which leads to obesity (Jahns, Baturin, \& Popkin, 2003). Obesity is a global lifestyle disease that is affecting millions of individuals around the world. Russia, like other developing countries, shows alerting trends in their obese statistics (Rtveladze et al., 2012). Russia is the largest former soviet country with a diverse and vibrant changing food culture. Russia has nine geographical time zones presenting a varying food consumption pattern (Rtveladze et al., 2012). These perspectives are all reflected in the literature review.

\subsection{Obesity Statistics in Russia}

Research shows that approximately $60 \%$ of Russians are currently overweight, among which $20 \%$ of them are obese (Yuen \& Chu, 2019). The current state shows an increased risk of the disease. According to a 25-year study conducted to investigate obesity trends in Russia, the lifestyle problem had attained a $45.5 \%$ increase between 2011 and 2016 (Alter, 2018, para. 2). The study showed that 856 out of 100,000 Russian individuals were regarded obese in 2011, a number which held at 1245 in 2016 (Alter, 2018, para. 4). Other studies conducted to examine obesity prevalence in Russian adults aged between 26 - 64 years show that the trend is decreasing in educated men but not women (Kontsevaya et al., 2019: p. 104).

Obesity statistics in Russia do not show many variations with gender. According to research conducted by Kontsevaya et al., overall rates of obesity are higher in women than men though the trend might change with time (Kontsevaya et al., 2019: p. 104). The study shows that the burden of obesity is shifting towards the low socioeconomic class (Kontsevaya et al., 2019: p. 104). The research further found that BMI increased with age translating to $83.1 \%$ of the 55 64 age group as overweight and $41.9 \%$ between 25 - 34 years (Kontsevaya et al., 2019: p. 104). There is no published academic research that gives insight into the cost of dealing with obesity in the Russian Federation, however considering that Russia and the USA have similar obesity trends, in time, health-related costs will be as significant as in the USA.

\subsection{Past Data on Obesity in USSR/Russian Federation and Comparison with the USA}

According to shifts in food consumption data occurring between 1950 and 1989, the Russian diet changed from starch dominance to meat, dairy products, and sugar (Jahns, Baturin, \& Popkin, 2003). Taking high calories food increase the hazards of the obesity epidemic (Bratanova et al., 2016). A study conducted on food consumption between 1950 and 1989 shows that a considerable number of the Russian population took food with high calories (Mowafi et al., 2014). Data collected about daily calories in both Russia and the USA show an increased calorie consumption in both countries since 1950 (Gould, 2017; Jahns, Baturin, \& Popkin, 2003). 
Figure 1 indicates the calorie intake in the United States between 1961 and 2013. There is an overall increasing trend in calorie intake in the US during the period. The figure shows that the United States' calorie intake between 1961 and 2013 was between 2880 and 3682. The individuals' calorie intake was above the daily recommended limit, which is 2000 for women and 2500 for men. The figure does not specify which type of food as it is an average for all classification. On the other hand, Figure 2 represents the calorie intake for different kinds of food in Russia between 1950 and 1989. The calorie intake during the period in Russia reveals the same trend as in the United States except for potatoes ( $\square$ ), which shows a decreasing trend (Jahns, Baturin, \& Popkin, 2003). The other lines in the graph represent the calorie intake of food such as milk $(\rightarrow-)$, bread $(-)$, red meat $(-)$ ) and sugar $(-)$ products. All categories have an increasing trend.

According to the study conducted in Russia and the USA between 1992-1998, overweight prevalence dropped from $15.6 \%$ to $9.0 \%$ in a period characterized by dreadful economic stress and reduction in density of the energy in a typical diet (Wang, Monteiro, \& Popkin, 2002). The study found that the overweight prevalence was higher in children than adolescence in Russia but was less in the USA (Wang, Monteiro, \& Popkin, 2002). The prevalence was also much higher in rural areas of Russia and the USA compared to other countries such as China and Brazil (Wang, Monteiro, \& Popkin, 2002). The research is supported by findings from Popkin and Gordon, which show a contrasting decrease in Russian obesity statistics between 1992-1998 by about $9.0 \%$ while the rest of the world experience an increase (Popkin \& Gordon-Larsen, 2016).

According to studies carried out between 2012 and 2014, approximately 30\% of Russian adults showed signs of obesity, which closely approaches figures in the USA, which are at 34.9\% (Kontsevaya et al., 2019: p. 104). Other research carried out between 2011 and 2014 found about $64.6 \%$ of Russian adults to have a BMI of more than $25 \mathrm{~kg} / \mathrm{m}^{2}$, which approaching USA prevalence level of $68 \%$ (Malik, Willett, \& Hu, 2013). According to a 25 -year study conducted to investigate obesity trends in Russia, the lifestyle problem had attained a $45.5 \%$ increase between 2011 and 2016 (Alter, 2018).

\subsection{Management Solutions for Obesity Effects}

Several researchers have proposed different methods of dealing with obesity. The following have gained attraction and can be considered risk management approaches.

- Probiotics: According to research on modulation of gut microbiota by probiotics, the study showed that the organism presents obesity controlling benefits to the host (Mazloom, Siddiqi, \& Covasa, 2019; Lee et al., 2014).

- Lifestyle Change: Other researchers suggest methods like state and local programs, community interventions, and a healthy lifestyle as a recommendable approach to preventing and managing obesity (CDC, 2019; Jeffery, 1991; McTiernan, 2016). 
DAILY CALORIES CONSUMED BY AMERICANS, 1961-2013

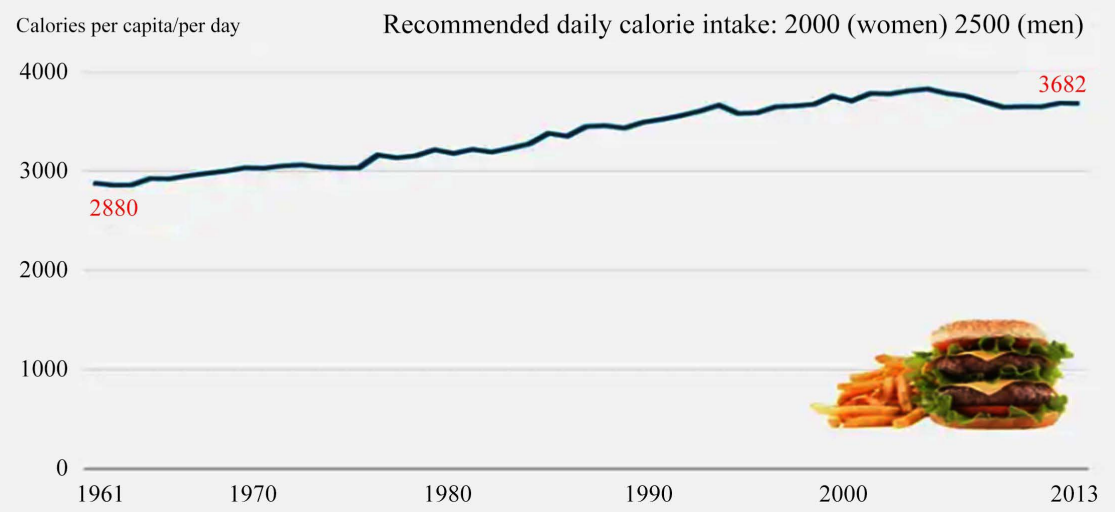

Figure 1. The USA recommended calorie uptake (Gould, 2017).

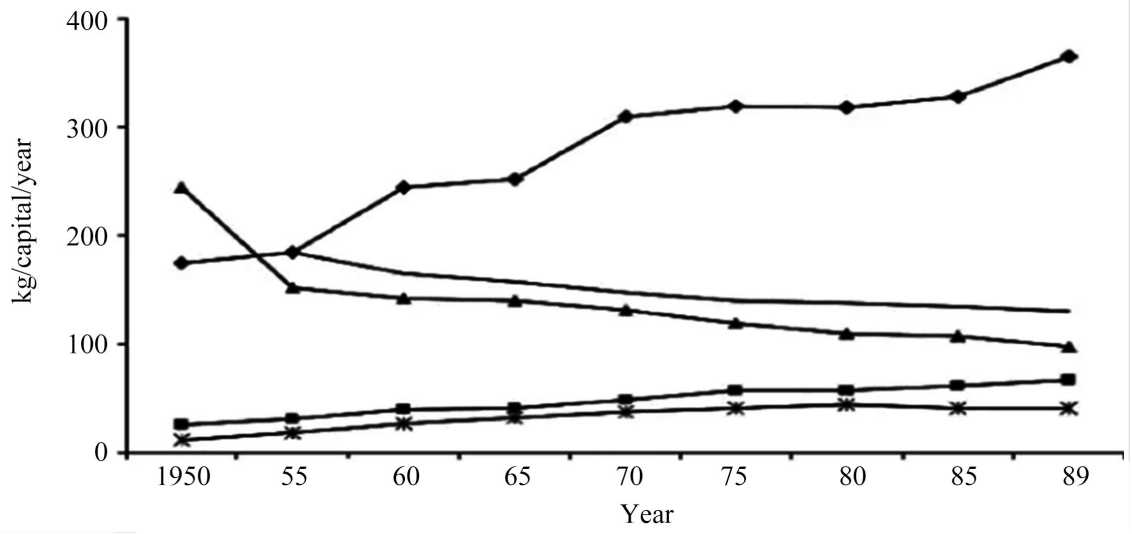

Figure 2. Russia Calories uptake (Jahns, Baturin, \& Popkin, 2003).

- Strategic Policy Approach: Governments plays a crucial role in the management of epidemics. According to research conducted to investigate the 2009 Australia and New Zealand health policy, the development of a methodical evidence-based program that gives feedback on the extent and scope of obesity together with cost-benefit analysis, are vital in obesity control projects (Allender et al., 2009). Other research conducted on Romp \& Chomp, a community based strategic intervention against obesity initiated between 2004 and 2008, shows a significant lowered BMI from and ZMI in young children (de Silva-Sanigorski et al., 2010). Multi-setting community-wide policies can mitigate early age obesity, improving the child's diets. Other studies carried out to investigate obesity in Australian Context found that a comprehensive strategic policy approach involving government, non-governmental, and private sectors can aid in mitigating the epidemic (Sacks, Swinburn, \& Lawrence, 2009).

- Formal Incentives: Some governments have developed policies to limit the consumption of foods which attribute to obesity. Studies show that artificially sweetened beverages should be discouraged as a composition of a healthful diet (Borges et al., 2017). According to reviews on the health planners' and 
practitioners' views, formal incentives and providing planners with public health leadership responsibilities are some of the projects that can reduce obesity (Lake, Henderson, \& Townshend, 2017).

- Promote Healthy Eating Among Children: The United States government has put in measures to address unhealthy eating habits, which results in obesity. The task force on childhood obesity has set up a marketing environment to promote healthy eating among children (Harris, Schwartz, \& Brownell, 2010: p. 2). In response, McDonald's and Burger, which are among the largest fast-food marketers to children, pledged to advertise what is healthy for the children after joining Children's Food and Beverage Advertising Initiative (CFBAI) (Harris, Schwartz, \& Brownell, 2010: p. 2). Many of the fast-food industries re-introduced more nutritious and healthier foods on their menu (Harris, Schwartz, \& Brownell, 2010: p. 2).

\section{Methodology}

This research follows qualitative methodology. Qualitative research is a type of social science research that collects and works with non-numerical data and that seeks to interpret meaning from these data that help understand social life through the study of targeted populations or places (ThoughtCo, 2020).

\subsection{Scope of the Research}

In the study, benchmarking data will be used to position the Russian perspective more accurately relative to other counties. The intended population of this research consists of Russian Federation residents. Russian population is 145,910,612 (Worldometers.info, 2020). There are at least 650 McDonald's restaurants throughout Russia now and the fast-food chain is thriving in the country (Business Insider, 2020). Russian traditional cuisine is very special consisting of meat dishes, vegetable salads, pink and black caviar, porridges, soups, borsch, pies and brown bread (Expat Guide to Russia|Expatica, 2020). The Russian traditional diet is considered a very balanced diet with all needed nutrients and vitamins. Russia is a perfect example how fast food spreading caused a national problem of obesity.

The sample population surveyed includes people aged 10 years and above and focuses on the Rights of a Child. Article 57 of the Russian Family Code provides that if a child is 10 years old or older, its opinion must be "considered". If the child's opinion is not followed, the parents who disregard its opinion must sufficiently explain the grounds therefore. The wishes of a child of 10 years or older can only be overruled under special circumstances (Antokolskaia, 2020). Article 12 of the UN Convention urges consideration of a child's opinion in light of the child's ability to formulate it. The Russian Supreme Court, in its Directive No. 10 of 27 May 1998, also obliged judges to investigate whether a child has been unduly influenced by the litigating parties, whether the child is aware of his or her interests, and on what grounds the child has reached his or her opinion (Anto- 
kolskaia, 2020). This includes both males and females.

The goal is to limit the scope to people that truly lived in Russian environments and were fully exposed to Russian culture. Russians that currently lived abroad are not included nor represented in this survey. Interviewees were not Russian residents. Subject matters experts' opinions were collected from countries that face obesity prevention problem. Due to COVID-19 breakdown in 2020, the author had to conduct all surveys and interviews online via Survey Monkey, LinkedIn, Instagram, Facebook and Emails.

\subsection{Data Collection}

\section{Case Study}

A case study approach is particularly useful to employ when there is a need to obtain an in-depth appreciation of an issue (Comparison of Exclusion, 2020). During the pre-research period, the issue was identified. McDonald's is the largest fast-food marketer to children (Harris, Schwartz, \& Brownell, 2010: p. 2). The case study analysis of fast food outlets McDonald's would be used to analyze their marketing strategy towards children. The question investigated in this study was, "will a decline in children-oriented marketing campaigns cause lower obesity levels and associated economic and social problems?"

Four propositions are identified: gifts to children make them want fast food more; less consumption of fast food will lead to a healthier life; less consumption of fast food will stimulate cognitive abilities in children; a decline in obesity rates will result in a healthier economy. The first proposition is based on the notion that gifts would stimulate the children to buy those food items that are not allowed by their parents. The second proposition is based on the notion that less consumption of fast food would reduce the risk of obesity and ensure a healthy life. The third proposition is based on the notion that less consumption of fast foods would increase the intake of non-fat food items such as vitamins, minerals, and proteins and carbohydrates that would improve cognitive functioning. Finally, the fourth proposition was based on the notion that reduction in obesity would lead to higher physical fitness that would translate into a productive workforce and stimulated economy.

\subsection{Data Analysis}

\section{$\underline{\text { Interviews }}$}

Interviewing is a qualitative research technique which involves conducting intensive individual interviews with a small number of respondents to explore their perspectives on a particular idea, program or situation (Research-Methodology, 2020). Interviews took place concurrently with the survey (see page 37). Interviews were designed and distributed in English language. Interviewees were not Russian residents. Experts opinions were collected from countries that face obesity prevention problem. Due to COVID-19 breakdown in 2020, the author had to conduct all interviews online. 
Health policy makers and Health Economics Professors were interviewed through email and LinkedIn to seek a professional opinions on different aspects such as: would decline in children oriented fast food marketing campaigns cause lower obesity levels and associated economic and social problems in the Russian Federation; would government restriction to sell fast food in schools cause reduction in obesity rates; and is there a link between fast food marketing in childhood and fast food consumption in adult life. The interview transcripts were coded and thematically analyzed in comparison to the literature obtained. The interview responses were thematically coded and interpreted based on the themes that were identified in the secondary data. The research also identified novel ideas and findings that were latent in previous studies.

Thirty-four messages were sent through LinkedIn to World Health Organization Leaders and Government policy makers. Also, fifteen emails were sent to Health Economics Professors. Also, I was lucky to get a response from Health Policy Maker in the Australian Government, as well as a Health Coordinator from World Health Organization.

Interview Questions: Appendix 2 has all the interview information summarized in the detail (See p. 59) (Figure 3).

Survey

The study was conducted as a survey since the present study only involved various stakeholders with different designations and job functions. Survey is a method of gathering information from a sample of people, traditionally with the intention of generalizing the results to a larger population (Qualtrics, 2020). Survey was designed and distributed in English and Russian languages. The author started to evaluate survey results in March and finished in April.

Data were collected using a survey designed and hosted by Survey Monkey. Survey Monkey is a platform designed to help collecting surveys and automatically analyze results (How it works|SurveyMonkey, 2020). The information obtained was not recorded in a manner that human subjects could be identified. A convenience sample was used, and the survey link was posted on different online sites, such as Facebook and Instagram as well as sent to friends and relatives. Survey results were analyzed by using Microsoft Excel. The survey data was coded and thematically analyzed in comparison to the literature obtained (Figure 4).

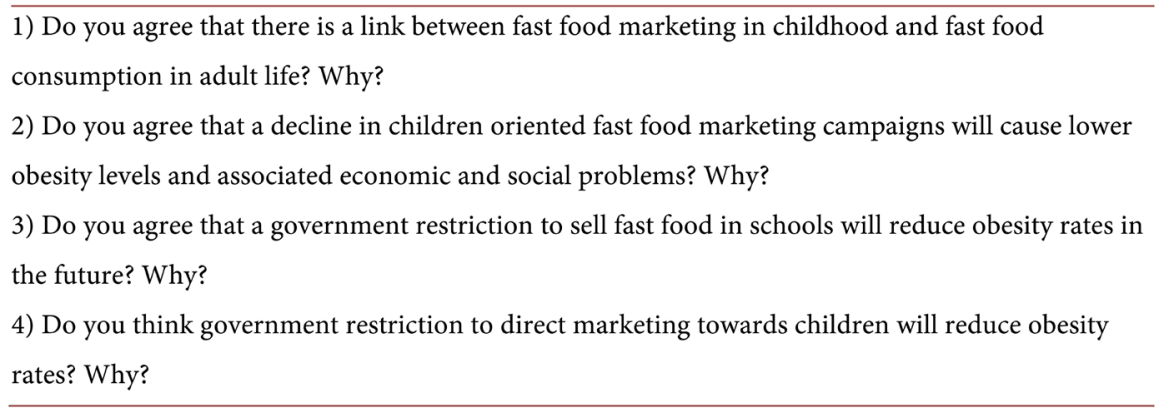

Figure 3. Interview questions. 
1) What is your country of residence?

2) How old are you?

3) Below are listed 8 government policies that are considered to reduce the prevalence of obesity in Russian population. Please choose "YES" if you agree to the new regulation, or "NO" if you disagree.

a) Implement tax on sugar.

b) Create education programs through public health leadership such as sending health professional to schools as means of driving education \& developing healthier habits.

c) Force all Russian fast-food industries to re-introduce more nutritious and healthier foods on their menu.

d) Force standardization on Russian food labeling on calorie content in products, not only in $100 \mathrm{~g}$ but also in total package.

e) Forbid to sell fast food and artificially sweetened beverages to children in schools.

f) Forbid to direct any fast food \& sugary drinks marketing towards children.

g) Forbid to give any sort of incentives such as toys to children after purchasing fast-food.

h) Stream free to air TV "Food \& Fitness" channel with workouts and exercises tips for daily life.

Figure 4. Survey questions.

\subsection{Ethics}

Research ethics takes important place in the research methodology because it provides guidelines for the responsible conduct of research. In addition, it educates and monitors scientists conducting research to ensure a high ethical standard. Some ethical principles: Honesty; Objectivity; Integrity; Carefulness; Openness; Respect for Intellectual Property; Confidentiality; Non-Discrimination; Competence; Legality; and Human Subjects Protection (Research Guides: Research Methods: Ethics in Research, 2020). Ethical issues concern next planning of the research: how to get access to information, people, data and the data collection, organizing and reporting (Saunders et al., 2009).

Due to the absence of ethics committee at Russian Precedential Academy, the survey and interviews questions were approved by academic supervisor Sarah Ross once trialed with pilot groups. The information obtained during survey and interviews was not recorded in a manner that human subjects could not be identified. The questions for the interviews and surveys have been elaborated in a neutral way, in order to not force one of the participants to say something that she or he did not want to say, and to not influence a certain type of answer. Moreover, all the information about the participants will never be disclosed under any circumstances. All the participants were aware of the non-disclosure agreement term before answering to the interview or survey questions. The research design of his study was not harming or embarrassing to any participants of this study.

The participants had a chance to receive the data collected after completion of the data collection program. The author individually contacted the interview participants. Additionally, survey participants could see the results statistics right after completion upon request. I being the author, promise to provide all ob- 
tained information in this paper and if necessary, per request, provide any additional information as a proof of the survey and interviews conducted.

\section{Mcdonald's Case Study}

McDonald's is among the most successful fast-food brands across the world, partly because of its strategic approach to marketing. The company uses multiple marketing platforms such as social media, out of home, print, and TV ads to get their message across a broad and diverse audience (Guran \& Bereket, 2011: p. 484). Customer perception is a key determinant of success for any marketing strategy. McDonald's has been accused of several of negligent practices for refusing to address the impact of fast foods and predatory marketing on children. McDonald's has failed the address the contribution of the predatory market to the rise in obesity and other lie style diseases in children.

McDonald's uses a demographic segmentation strategy that considers age as the parameter. McDonald mainly targets children, youth, and young families in urban areas (Smits et al., 2015: p. 316). Children especially affected by predatory marketing of fast food joints because they are attracted to fast foods and toys. The increase in fast food consumption partly causes the rising rate of childhood obesity in the US (Harris, Schwartz, \& Brownell, 2010: p. 1). Fast food joints have an ethical responsibility to address their impacts on public health, especially among children.

\subsection{SWOT Analysis}

A SWOT Analysis reveals that McDonald's has various strengths that help grow the brand. First, McDonald's is a global brand that appeals to persons of all ages. It has been ranked among the top 100 global brands (Ceil, 2017: p. 36).

- In terms of strengths the company has a strong operational capacity, which enhances its ability to serve millions of customers without wavering on quality and experience. It has a world-class supply chain and customer service. Lastly, McDonald's has various successful products on the menu, such as the Big Mac and Chicken McNuggets, which have become strong brands on their own right (Dixit, 2017: p. 871).

- In terms of weaknesses, McDonald's has low revenue growth, which indicates that it has not been able to attract additional customers to its restaurants. Also, McDonald's has weak product development as it has only offered a limited range of products over the years. The company is slow to innovate and try new ideas.

- In terms of opportunities, McDonald's much potential to expand further by opening new branches across the world. Additionally, the dining out culture is increasing, which provides the opportunity to attract more customers.

- In terms of threats, McDonald's faces tough competition both locally and abroad from other major fast-food franchises and restaurants (Ceil, 2017: p. 36). Therefore, McDonald's must compete based on pricing, quality, and customer convenience. Another key threat is the growing consciousness about 
the impacts of fast foods on health.

\subsection{McDonald's Marketing to Children}

Children are among the top consumers of purchased food products in the US. Therefore, fast food joints such as McDonald's have adopted strategies of marketing to children. For example, McDonald's attracts children through the happy meals menu in which a child is given a free toy for every happy meal they purchase. The toys range from hot wheels to the various fictional characters on Disney (Sonntag et al., 2015: p. 8569). In various branches, McDonald's has a dedicated "playing place" for children to play a wide range of games such as hockey. This strategy helps to sell McDonald's as a fun place where families can eat as their children play. As noted above, consumer perception is a key factor influencing the success of marketing strategies. By creating the perception of being a child-friendly place, McDonald's has been able to win over millions of urban families across the US. McDonald's has positioned itself as an affordable place to eat that does not compromise on the quality of food and hygiene. However, the quality of the food is objectionable, considering the negative health impacts it has.

Child-oriented marketing of fast foods to children is one of the leading causes of childhood obesity in developed countries. Obesity is the natural response to an environment filled with energy-dense foods that are constantly marketed to people (Andreyeva et al., 2011: p. 224). Children are particularly susceptible to the persuasive messages coded in advertisements because they are still developing cognitively. For example, a child in the pre-cognitive stage cannot differentiate between a commercial and a television program.

Children often perceive the messages in advertisements as factual. Research indicates that some children use advertisements as a source of information for what is on the shelves (Paul \& Roy, 2014: p. 103). Therefore, the marketing of fast foods to children is an unfair practice because it exploits their cognitive limitations. It is also a breach of the child's right to information under the United Nations Convention for the Rights of the Child. According to Sadeghirad et al. (2016: p. 948), acute exposure to fast food advertisements influences a child's behavior and attitude towards the consumption of unhealthy products. The SWOT analysis shows that McDonald's is a major brand and has major influence over the community (Boyland et al., 2015: p. 1012). The question of whether the company should be allowed to continue to advertise to children is an ethical one.

Lastly, marketing to children and the rise of childhood obesity are related factors. This is because fast foods accommodate more than $40 \%$ of all food advertisements aimed at children. Therefore, McDonald's' targeting of children for advertisement is the exploitation of the children. Policymakers and public health officials have a responsibility to protect consumers, especially the vulnerable ones, from exploitative corporate practices. Childhood obesity is likely to keep increasing if fast food advertisements targeting children are not regulated (Figure 5). 


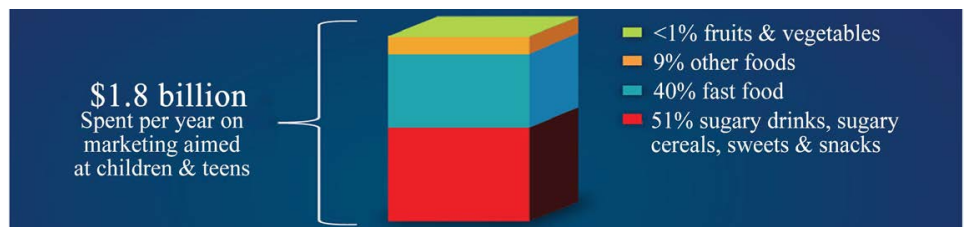

Figure 5. The truth about food marketing (LoDolce, 2015, n.p).

\section{Interviews \& Survey}

\subsection{Interviews}

The research interviewed three interviewees who acted at different capacities in the health sector to remove biases from the study. The first interviewee was a government civil servant with 20 years of experience working in the health policy sector. The second was a Health Sector Activist working with the World Health Organization and having five years of experience. The last interviewee was a Health Economics Professor with 22 years of experience currently a University professor. The choice of the interviewees took into aspect the health part and the economics part, which considers the effects of adopting some adverse changes in fast-food marketing. All the interviewees agreed that there was a substantial amount of evidence to link fast food marketing strategies in the early years of a child, which grows into adulthood eating habits.

- Respondent 1:

"Absolutely, there's a lot of examples that demonstrate early learnings (positive or negative) can flow through to adulthood. Overweight and obese children typically grow into overweight and obese adults, who are susceptible to chronic complaints such as diabetes and cardio vascular disease". (...) (Respondent 1, Government worker from health policy sector, Appendix 2 p. 60)

- Respondent 2:

"Some people say that children don't understand persuasive intent until they are older. However, cognitive structures are still being formed in the brain, making children more susceptible to external influences. One research, don't remember the name, found that children don't realize that athletes in television commercials are paid to promote products. They also believe that children in advertisements are real rather than paid actors, and they confuse advertisements with news items. Older kids, even more exposed because they are forming their adult identities and are susceptible to societal pressures to meet certain standards". (...) (Respondent 2, Health Sector Activist from WHO, Appendix 2 p. 62)

- Respondent 3:

"Obesity is a complex disease that can start in the childhood and then follow you for the rest of your life. Kids are easy to trick. Hide a ball behind your back and you can convince them it mysteriously disappeared. It's well known that brand equity is easier to establish with children and likely to stay relevant well into adulthood due to its nostalgic nature. If a company wanted to start building brand recognition and loyalty early, they should begin with kids as soon as possible". (...) (Respondent 3, Health Economics Professor, Appendix 2 p. 64) 
The interviewees unanimously held that childhood habits are more likely to be carried to an adult life due to the nostalgic effect. The advertisers may claim that children are unaware of their actions, but the interviewees refuted this school of thought. Reducing or limiting fast-food marketing campaigns would help children to be exposed to better eating habits. However, the drive to have restrictions on fast food marketing would be such a process because of the economic impact on society. It would mean the closure of some industries hence the loss of jobs.

- Respondent 3:

"It depends on what's been marketed to children and who has the bigger budget to get their attention. We need to find the balance between education on things like portion control while also accommodating capitalism and consumerism". (Respondent 3, Health Economics Professor, Appendix 2 p. 65)

Nonetheless, eliminating fast foods is not the solution to the problem of obesity. A counteractive measure should be employed that makes healthier alternatives readily available in places where young people love to visit, such as fields of play. This would ensure that no jobs are lost and also result in improved healthcare.

\subsection{Survey}

The survey objectives were few and were considering how people would react to certain adjustments by key players in the food industry (Table 2).

The first in line was to find out how people responded to an effort to seek to implement a tax on sugar would turn out. This is in consideration that most fast food industries chiefly use sugar in their foodstuffs. The majority won with a slight difference of only $10 \%$. 55\% of people interviewed accepted the idea to implement a tax on sugar, while $45 \%$ did not agree with the opinion. In the second survey objective, $100 \%$ of people agreed that educational programs should be created through public health leadership, such as sending health professionals to schools to educate young children on healthier habits. They trusted education as the best form of passing information to young children.

Table 2. Survey results.

\begin{tabular}{lcc}
\hline Policy & Yes & No \\
\hline Implement a tax on sugar & $55 \%$ & $45 \%$ \\
Educational programs should be created through public health leadership & $100 \%$ & $0 \%$ \\
Force fast-food industries to re-introduce more nourishing healthier foods & $97.50 \%$ & $2.50 \%$ \\
Force standardization on Russian food labeling on the total calorie & $90 \%$ & $10 \%$ \\
$\begin{array}{l}\text { content should not be restricted to } 100 \text { g but the whole package } \\
\text { Prohibit the selling of fast foods and artificially sweetened beverages }\end{array}$ & $87.50 \%$ & $12.50 \%$ \\
to young children in learning institutions & $85 \%$ & $15 \%$ \\
$\begin{array}{l}\text { Curb the directing of fast foods and sugary drinks to children in the } \\
\text { advertising and marketing industry }\end{array}$ & $35 \%$ & $65 \%$ \\
Children should not be given incentives such as toys after buying fast food \\
$\begin{array}{l}\text { Airing of a free to air TV channel with the major themes being food and fitness } \\
\text { without exempting workouts and exercises }\end{array}$ & $95 \%$ & $5 \%$ \\
\hline
\end{tabular}


A majority of people wanted the government to force fast-food industries to re-introduce more nourishing healthier foods on their products. $97.50 \%$ supported that the industries should be forced to comply, while $2.50 \%$ refused. Most Russians are intelligent about their health and the need to have a healthy society. Further, $90 \%$ of Russians want the government to force standardization on Russian food labeling on the total calorie content should not be restricted to $100 \mathrm{~g}$ but the whole package. $10 \%$ of the citizens do not see the need for forcing standardization by the government on industries to the label calorie content in the entire package.

In another objective, $87.50 \%$ of Russians supported the idea to prohibit the selling of fast foods and artificially sweetened beverages to young children in learning institutions. $12.50 \%$ concluded that it is not forthright to forbid the sale of fast foods and artificially sweetened beverages in schools. $85 \%$ of people urged the government to curb the directing of fast foods and sugary drinks to children in the advertising and marketing industry. In another objective under study, $65 \%$ of interviewees refused that children should not be given incentives such as toys after buying fast food. In comparison, 35\% did not see any problem with it. In the last survey objective, $95 \%$ of people advocated for the airing of a free to air TV channel with the major themes being food and fitness without exempting workouts and exercises hints for prodder daily living. 5\% did not support the idea.

\section{Findings and Propositions Summarized}

The study came up with the following findings and propositions on the ethical considerations of obesity levels in the Russian Federation. The study found out that Russia is severely impacted by obesity and its results. Most people are concerned about their health conditions and that of their children. More than $50 \%$ of the population is advocating that the government should implement measures that would help to promote good health amongst its feature generation. The Russians are calling on the responsible bodies to ensure that the industries indicate the total amount of calories in a package, ban the selling of sugary foods in schools.

Moreover, enterprises should re-regenerate themselves to start producing healthier foods to ensure that no jobs are lost. Also, it is essential to say that depression can result in the psychological effect of being overweight. Changing the line of production to a healthier diet would shake the economy for a small period, but the health benefits and savings in healthcare cost reduction will outweigh that gap. It is also indisputable that there is a link between fast food marketing in childhood and their consumption into adulthood. According to Pavlov's theory, social behaviors such as eating are carried throughout someone's life, and that is the same with children and fast foods.

The World Health Organization (2019) defined obesity as a condition of surplus body fat, which makes the number and size of body fat cells to enlarge. The 
researcher went in-depth from 1950 to date to find a broad view and the trends in fast food marketing. It looked at how things were done in the past, how they have transformed till to date, and how the future is likely to be. According to Jahns, Baturin, and Popkin (2003), it is indisputable that calorie consumption has steadily increased since 1950 , which is a significant contributor to obesity. Obesity is a challenging health problem in all developed countries, and the developing countries are also joining the trend. Russia is an exception amongst the other communist countries. It enjoys a diverse food economy due to the nine different time zones; it has hence allowed for varied food consumption patterns.

Several propositions were recommended from the study. First, the public should be educated about their health to ensure that they engage in healthy practices. Secondly, it is necessary to prioritize children's education, especially in a healthy diet, physical fitness, and exercise. Finally, the industries should stop considering the profits they bank each financial year and also seek to improve people's health by emphasizing healthy practices to improve the health of the people. Finally, the government should weigh the risk of letting their citizens consume whatever is manufactured but the profit-oriented industries to that of putting restrictions on production guidelines.

\section{Conclusion on Questions and Objectives}

To know whether there is a link between fast food marketing in childhood and fast food consumption in adult life, the researchers analyzed data on past, current and projected levels of obesity since 1950-2050 in comparing the USA and USSR/Russian Federation over the same period. The research used a case study of the McDonald's fast-food outlet to examine their strategy of marketing that targets children. It assisted in knowing whether a decline in children-oriented fast-food marketing campaigns would cause lower obesity levels and associated economic and social problems. In the third objective, the research sought to determine if a Russian Government Portfolio Management Framework would reduce the risks to the Russian economy with regards to the approach hence reducing obesity rates among children.

The research defined obesity as the condition of excess body fat due to which the number and size of fat cells increase. Research indicated that more the $60 \%$ of the Russian population are overweight and amongst them $20 \%$ are obese, which closely approaches figures in the USA. The research employed a qualitative methodology since the survey questions would help to identify if stakeholders agree to the new policy measures. It also used a cross-sectional approach because the prevalence of obesity and the marketing of fast foods would not suddenly change in the target population. The technique combined a qualitative approach to understand the aspects behind the cause-and-effect relationships between the observations.

The research concluded that there is a link between fast food marketing in childhood and fast food consumption in adult life and that the risk-based ap- 
proach to Portfolio Management Framework at Government Level will lead to decreased obesity rates among children. Government Portfolio should include: tax on sugar; educational programs through public health leadership; more nourishing healthier foods among fast-food industries; standardization on Russian food labeling on the total calorie content; policy on not selling fast foods and artificially sweetened beverages to young children in learning institutions; policy on not marketing fast foods and sugary drinks to children in the advertising industry. Also, 95\% of Russians voted to air TV channel with the major themes being food and fitness without exempting workouts and exercises.

\subsection{Recommendation for Further Research}

Based on the results of the study, there is still a gap that needs more research to include ways through which people can get enough information to keep healthy. The relevant programs still lack and should be identified to ensure that people get the necessary knowledge to overcome the problem. More studies should explore how to implement various ethical considerations using modern ways of communications, such as social media platforms. Filling this gap will ensure that more recommendations are given to guide the means through which the government can enforce various regulations to combat the large intake of calories that some companies produce excessively. The studies that exist do not address some of the measures that the public should take to ensure the reduction of obesity. Comprehensive research on the best actions to mobilize the public will help the government in making federal laws that can limit the spread of fast food industries. Also, further research is needed on the question: "Will a decline in children-oriented fast-food marketing campaigns cause lower obesity levels and associated economic and social problems?"

\subsection{Reflection of Lessons Learned}

People are still ill-informed about the recommended food that they should take to protect them from obesity. Some people take foods that put their life at risk without knowing the future negative impacts. They need special education to ensure that they engage in the best practices that will improve their welfare. Most individuals are willing to advocate for better eating habits but cannot manage to do so because of a lack of knowledge. People are concerned about their children, but they cannot find better options on how to feed them. The daily food consumption puts the lives of children at risk that may result in future effects that may be irreversible and harmful. More research is necessary to equip people with more knowledge to ensure that they nurture their children to practice eating habits that will protect them from obesity.

\section{Acknowledgements}

This study has been duly completed with the support of the Project Management Program Director Mitali Mittra, university staffs and experts.

The author is very grateful for a huge support from her advisor Sarah Ross. 
Sarah was always there, helped and guided the author through rough circumstances and even though the author was in a foreign country, she was still able to finish the research.

Also, the author wants to thank the Australian Government for extending her visa and allowing her to stay longer in Australia, due to the COVID-19 circumstances.

Dear interviewees, that decided to participate, thank you for answering. Thank you for giving the author some of your time and helping her research. This research would not be possible without you.

Finally, this research would not exist without author's friends and relatives, that besides being under coronavirus lockdown, still were willing to complete her surveys.

\section{Conflicts of Interest}

The author declares no conflicts of interest regarding the publication of this paper.

\section{References}

Allender, S., Gleeson, E., Crammond, B., Swinburn, B., Lawrence, M., Peeters, A., Loff, B., \& Sacks, G. (2009). Moving beyond "Rates, Roads, and Rubbish": How Do Local Governments Make Choices about Healthy Public Policy to Prevent Obesity? Australia and New Zealand Health Policy, 6, Article No. 20. https://doi.org/10.1186/1743-8462-6-20

Andreyeva, T., Kelly, I. R., \& Harris, J. L. (2011). Exposure to Food Advertising on Television: Associations with Children's Fast Food and Soft Drink Consumption and Obesity. Economics \& Human Biology, 9, 221-233. https://doi.org/10.1016/j.ehb.2011.02.004

Borges, M. C., Louzada, M. L., de Sá, T. H., Laverty, A. A., Parra, D. C., Garzillo, J. M. F., Monteiro, C. A., \& Millett, C. (2017). Artificially Sweetened Beverages and the Response to the Global Obesity Crisis. PLoS Medicine, 14, e1002195. https://doi.org/10.1371/journal.pmed.1002195

Boyland, E. J., Kavanagh-Safran, M., \& Halford, J. C. (2015). Exposure to "Healthy" Fast Food Meal Bundles in Television Advertisements Promotes Liking for Fast Food but Not Healthier Choices in Children. British Journal of Nutrition, 113, 1012-1018. https://doi.org/10.1017/S0007114515000082

Bratanova, B., Loughnan, S., Klein, O., Claassen, A., \& Wood, R. (2016). Poverty, Inequality, and Increased Consumption of High-Calorie Food: Experimental Evidence for a Causal Link. Appetite, 100, 162-171. https://doi.org/10.1016/j.appet.2016.01.028

Ceil, C. (2017). Service Quality and Branding Strategies at McDonald's. https://doi.org/10.2139/ssrn.2984100

de Silva-Sanigorski, A. M., Bell, A. C., Kremer, P., Nichols, M., Crellin, M., Smith, M., Sharp, S., de Groot, F., Carpenter, L., Boak, R., \& Robertson, N. (2010). Reducing Obesity in Early Childhood: Results from Romp \& Chomp, an Australian Community-Wide Intervention Program. The American Journal of Clinical Nutrition, 91, 831-840. https://doi.org/10.3945/ajcn.2009.28826

Dixit, D. (2017). Global Marketing Strategies of McDonald's Corporation (with Reference to India and Russia). IJAR, 3, 870-875.

Expat Guide to Russia|Expatica (2020). Food and Drink: Russian Cuisine-A Guide to Cuisine. 
https://www.expatica.com/ru/about/cuisine/food-and-drink-russian-cuisine-104066/

Gould, S. (2017). 6 Charts That Show How Much More Americans Eat than They Used to. Business Insider.

https://www.businessinsider.com/daily-calories-americans-eat-increase-2016-07? IR=T

Guran, T., \& Bereket, A. (2011). International Epidemic of Childhood Obesity and Television Viewing. Minerva Pediatrica, 63, 483-490.

Harris, J. L., Schwartz, M. B., \& Brownell, K. D. (2010). Evaluating Fast Food Nutrition and Marketing to Youth. New Haven, CT: Yale Rudd Center for Food Policy \& Obesity.

Jahns, L., Baturin, A., \& Popkin, B. M. (2003). Obesity, Diet, and Poverty: Trends in the Russian Transition to a Market Economy. European Journal of Clinical Nutrition, 57, 1295-1302. https://doi.org/10.1038/sj.ejcn.1601691

Jeffery, R. W. (1991). Population Perspectives on the Prevention and Treatment of Obesity in Minority Populations. The American Journal of Clinical Nutrition, 53, 1621S-1624S. https://doi.org/10.1093/ajcn/53.6.1621S

Kontsevaya, A., Shalnova, S., Deev, A., Breda, J., Jewell, J., Rakovac, I., Conrady, A., Rotar, O., Zhernakova, Y., Chazova, I., \& Boytsov, S. (2019). Overweight and Obesity in the Russian Population: Prevalence in Adults and Association with Socioeconomic Parameters and Cardiovascular Risk Factors. Obesity Facts, 12, 103-114. https://doi.org/10.1159/000493885

Lake, A. A., Henderson, E. J., \& Townshend, T. G. (2017). Exploring Planners' and Public Health Practitioners' Views on Addressing Obesity: Lessons from Local Government in England. Cities \& Health, 1, 185-193. https://doi.org/10.1080/23748834.2017.1393243

Lee, H., Wildeman, C., Wang, E. A., Matusko, N., \& Jackson, J. S. (2014). A Heavy Burden: The Cardiovascular Health Consequences of Having a Family Member Incarcerated. American Journal of Public Health, 104, 421-442. https://doi.org/10.2105/AJPH.2013.301504

Libguides.library.cityu.edu.hk. (2020). Research Guides: Research Methods: Ethics in Research. https://libguides.library.cityu.edu.hk/researchmethods/ethics

LoDolce, M. (2015). Food Marketing to Children: A Wolf in Sheep's Clothing. https://www.obesityaction.org/community/article-library/food-marketing-to-childrena-wolf-in-sheeps-clothing/

Malik, V. S., Willett, W. C., \& Hu, F. B. (2013). Global Obesity: Trends, Risk Factors, and Policy Implications. Nature Reviews Endocrinology, 9, 13-27. https://doi.org/10.1038/nrendo.2012.199

Mazloom, K., Siddiqi, I., \& Covasna, M. (2019). Probiotics: How Effective Are They in the Fight against Obesity? Nutrients, 11, 258. https://doi.org/10.3390/nu11020258

McTiernan, A. (2016). Cancer Prevention and Management through Exercise and Weight Control. Boca Raton, FL: CRC Press. https://doi.org/10.1201/9781420026641

Mowafi, M., Khadr, Z., Kawachi, I., Subramanian, S. V., Hill, A., \& Bennett, G. G. (2014). Socioeconomic Status and Obesity in Cairo, Egypt: A Heavy Burden for All. Journal of Epidemiology and Global Health, 4, 13-21. https://doi.org/10.1016/j.jegh.2013.09.001

Paul, R., \& Roy, S. K. (2014). Case Study 11: Marketing of Services: The McDonald's Way. In D. Mutum, S. Roy, \& E. Kipnis (Eds.), Marketing Cases from Emerging Markets (pp. 99-112). Berlin, Heidelberg: Springer. https://doi.org/10.1007/978-3-642-36861-5_15

Popkin, B. M., \& Gordon-Larsen, P. (2016). Chap. 4. An International Perspective on Pediatric Obesity. In M. I. Goran, \& M. S. Sothern (Eds.), Handbook of Pediatric Obesity: Etiology, Pathophysiology, and Prevention (p. 53). Boca Raton, FL: CRC Press. 
Rtveladze, K., Marsh, T., Webber, L., Kilpi, F., Goryakin, Y., Kontsevaya, A., Starodubova, A., McPherson, K., \& Brown, M. (2012). Obesity Trends in Russia. The Impact on Health and Healthcare Costs. Health, 4, 1471-1484.

https://doi.org/10.4236/health.2012.412A212

Sacks, G., Swinburn, B., \& Lawrence, M. (2009). Obesity Policy Action Framework and Analysis Grids for a Comprehensive Policy Approach to Reducing Obesity. Obesity Reviews, 10, 76-86. https://doi.org/10.1111/j.1467-789X.2008.00524.x

Sadeghirad, B., Duhaney, T., Motaghipisheh, S., Campbell, N. R. C., \& Johnston, B. C. (2016). Influence of Unhealthy Food and Beverage Marketing on Children's Dietary Intake and Preference: A Systematic Review and Meta-Analysis of Randomized Trials. Obesity Reviews, 17, 945-959. https://doi.org/10.1111/obr.12445

Saunders, M., Lewis, P., \& Thornhill, A. (2009). Understanding Research Philosophies and Approaches. Research Methods for Business Students, 4, 106-135.

Smits, T., Vandebosch, H., Neyens, E., \& Boyland, E. (2015). The Persuasiveness of Child-Targeted Endorsement Strategies: A Systematic Review. Annals of the International Communication Association, 39, 311-337. https://doi.org/10.1080/23808985.2015.11679179

Sonntag, D., Schneider, S., Mdege, N., Ali, S., \& Schmidt, B. (2015). Beyond Food Promotion: A Systematic Review on the Influence of the Food Industry on Obesity-Related Dietary Behaviour among Children. Nutrients, 7, 8565-8576. https://doi.org/10.3390/nu7105414

Wang, Y., Monteiro, C., \& Popkin, B. M. (2002). Trends of Obesity and Underweight in Older Children and Adolescents in the United States, Brazil, China, and Russia. The American Journal of Clinical Nutrition, 75, 971-977. https://doi.org/10.1093/ajcn/75.6.971

Yuen, T. W. K., \& Chu, W. W. L. (2019). Association between Body Mass Index and Happiness in Africa, the Russian Commonwealth, Europe, Latin America, and South Asia. International Journal of Happiness and Development, 5, 141-159.

https://doi.org/10.1504/IJHD.2019.099360 


\section{Websites}

Alter, T. (2018). Russia's Obesity Rate Up Almost 50\% in 5 Years, Health Ministry Says. The Moscow Times.

https://www.themoscowtimes.com/2018/05/04/russia-obesity-rate-up-almost-50-in-5-y ears-health-ministry-a61355

Antokolskaia, M. (2020). National Report: Russia. Ceflonline.net. http://ceflonline.net/wp-content/uploads/Russia-Parental-Responsibilities.pdf

Business Insider (2020). I Ordered the Same Meal at a McDonald's in Moscow and New York City, and the Russian Location Was a Step up from the American One. https://www.businessinsider.com/mcdonalds-in-russia-versus-united-states-photos-me nu-2019-7\#the-first-mcdonalds-opened-in-the-ussr-in-january-1990-1

CDC (2019). Strategies to Prevent Obesity/Overweight \& Obesity/CDC. Cdc.gov. https://www.cdc.gov/obesity/strategies/index.html

Cdc.gov (2019). Body Mass Index (BMI)/HealthyWeight/CDC. https://www.cdc.gov/healthyweight/assessing/bmi/

Comparison of Exclusion (2020). BMC Medical Research Methodology. https://bmcmedresmethodol.biomedcentral.com/articles

Qualtrics (2020). How to Create a Great Survey. https://www.qualtrics.com/experience-management/research/survey-basics/

Research-Methodology (2020). Interviews-Research-Methodology. https://research-methodology.net/research-methods/qualitative-research/interviews/

SurveyMonkey (2020). How It Works/Survey Monkey. https://www.surveymonkey.com/mp/take-a-tour/?ut_source=megamenu

ThoughtCo. (2020). An Overview of Qualitative Research Methods. https://www.thoughtco.com/qualitative-research-methods-3026555

Whiteman, H. (2014). Worldwide Obesity Rates See "Startling" Increase over Past 3 Decades. Medical News Today. https://www.medicalnewstoday.com/articles/277450.php\#1

World Health Organization (2019). Overweight and Obesity. https://www.who.int/gho/ncd/risk_factors/overweight/en/

Worldometers.info (2020). Russia Population. Worldometer. https://www.worldometers.info/world-population/russia-population/ 